A. Sotnikov, A. Tantsiura, O. Lavrov

Ivan Kozhedub Kharkiv National Air Force University, Kharkiv, Ukraine

\title{
CALCULATING METHOD OF ERROR CALCULATIONS OF THE OBJECT COORDINATION BY MEANS OF CONDUCTING PLATFORM FREE INERTIAL NAVIGATION SYSTEMS OF A UNMANNED AERIAL VEHICLE
}

\begin{abstract}
A further development of the method of calculating the errors for the coordinates of the binding objects and the angle parameters of the orientation of unmanned aerial vehicles is obtained. Errors of determination of coordinates develop due to the impact of wind gust and turbulence of the atmosphere on light unmanned aerial vehicles. The main feature of the method is the ability to determine the error of the coordinates of the objects, depending on the direction and force of influence on the unmanned aerial vehicle. The magnitude of the external influence determines the value of the deviation from the trajectory of motion. The developed method can be applied with limited mass-size characteristics of an unmanned aircraft. It also determines the values of measurement errors regardless the distance between the points of measurement. Limitation to the application of the method can only be the ability of the appropriate sensors to measure the distance from the unmanned aircraft to the object of anchor. Possibilities of determining the coordinates of an object of binding with accuracy within units of measure are presented. This is achieved by measuring the angular coordinates with sensors of the navigation system accurately within a hundred miliradian. An algorithm for calculating the error of determining the coordinates of the binding object is presented. The algorithm is the further development of the sub-algorithm for calculating the angle parameters of the orientation of an unmanned aerial vehicle relative to the geographical coordinate system. The presented algorithm should be used before the start of the session of the correlation-extreme navigation system. The statistical simulation of the proposed method and algorithm is carried out. The results of the simulation indicate that the magnitude of the error of determining the coordinates of the binding object depends on the accuracy of the measurement of the angular parameters of an unmanned aerial vehicle. The results of the numerical estimation of the errors of measurement of coordinates of the binding objects are presented, depending on the accuracy of the measurement of the angular parameters of the unmanned aerial vehicle. The requirements for the accuracy of measuring the angular parameters of an unmanned aerial vehicle are determined, which provides a high accuracy of measuring the rectangular coordinates of the object of anchor.
\end{abstract}

Keywords : platform free inertial navigation systems, binding object, system of rectangular coordinates, angle of vision.

\section{Introduction}

Depending on the type of aircraft and the tasks assigned to it, the various types platform free inertial navigation systems (PFINS) are used to navigate it [1, 2]. The composition of such PFINS may vary depending on the requirements for their exact characteristics. The work $[3,4]$ shows the results of the analysis of the characteristics of some typical PFINS. The accuracy of the coordination of such systems varies from 5.5 to $37 \mathrm{~km} / \mathrm{h}$. Micromechanical gyroscopes and micromechanical accelerometers are generally used as sensitive elements in systems with low precision $[5,6]$.

At the same time, the PFINS, which is installed on the light and middle unmanned aerial vehicle (UAV) classes, is subject to the influence of external factors, in addition to the low accuracy of the coordinates. Such factors include turbulence in the atmosphere and wind gusts. This leads to the occurrence of additional errors in the measurement of angular and spatial coordinates of UAV. To solve this problem, algorithms are being developed that compensate the errors of sensitive elements [6].

The algorithm for determining the orientation parameters of PFINS consists of four sub-algorithms [7]:

1. Algorithm for determining the initial matrix of orientation.

2. Algorithm for calculating the matrix of the mutual orientation of the basis associated with UAV. This algorithm can be constructed on the basis of Poisson matrix modified solution of rotation equation or on using intermediate orientation parameters (RodrigoHamilton parameters).
3. Algorithm for calculating the angular parameters of the UAV orientation relative to the geographic coordinate (calculating the true course, roll, pitch).

4. Algorithm for converting the signals received from accelerometers to the geographical coordinate system for the use in the navigation algorithm.

The source of the algorithm information in the inertial orientation system is the angular velocity projection. They are obtained based on the signals of three sensors of angular velocities and calculated projections of the absolute-angular velocity of the geographical triangular $[8,9]$. However, the use of PFINS on small and middle UAV has limitations on the mass-grossing characteristics. In this case, the number of sensors can be reduced $[10,11]$. This makes it unnecessary to develop an appropriate calculation method and algorithm for determining the standard errors (SER) of the PFINS, in relation to the reduced number of sensors.

The purpose of the article is to develop a method of calculation and algorithm for determining the errors of the place of definition of the binding objects and angular coordinates of the UAV.

\section{The main material}

Let's consider the possibility of determining the errors of the PFINS by measuring the distances between the positions of the UAV, from which the measurements of the UAV to the object of bindings (OB) are carried out.

In fig. 1 rectangular coordinate system of the PFINS UAV position relative to $\mathrm{OB}$ is presented. It turns out that in order to determine the coordinates of 
the OB for geometric reasons it is necessary to determine at least two values of the angles of vision. That is, the measurement of the angle of reference must be made from two different positions of the UAV with known coordinates.

Let's assume that at the time $t_{0}$ PFINS makes measurements of the angle at a rate at point A. At the time $t$, PFINS makes measurements of the angle at a rate at point $\mathrm{B}$.

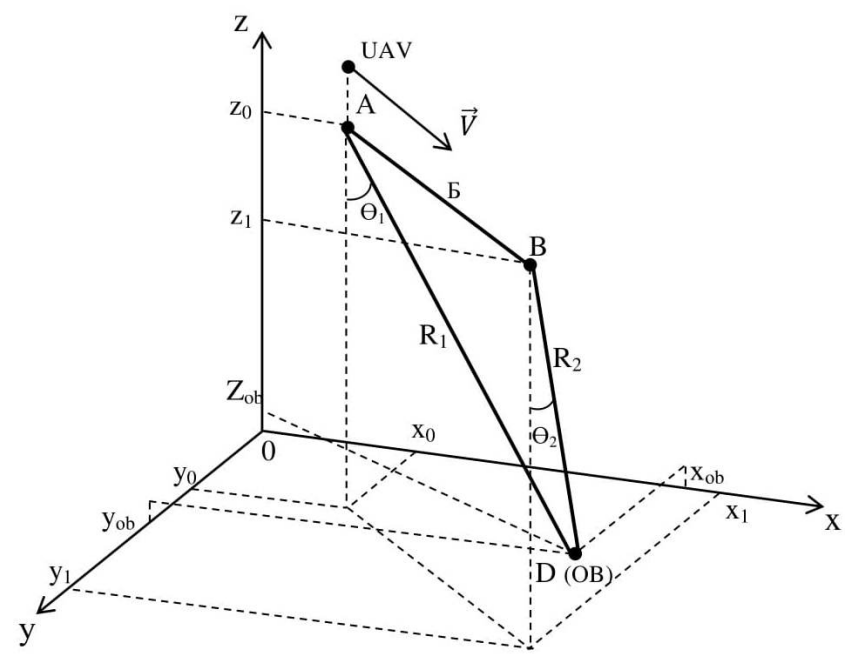

Fig. 1. Spatial position of the UAV relatively to the $\mathrm{OB}$ in the system of rectangular coordinates

Without lowering the generality of the considerations, it is assumed that the UAV is moving from point A to point $\mathrm{B}$ only in the area $\mathrm{xz}$ with the coordinate $\mathrm{x}$. Then the geometric conditions of the OB's visibility will be represented in accordance with fig. 2 .

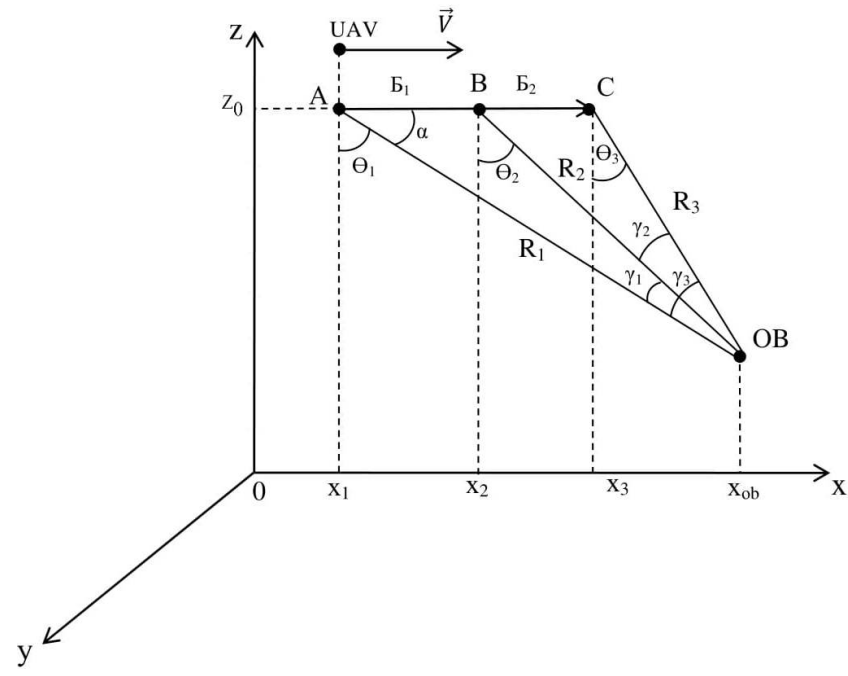

Fig. 2. Spatial position of UAV relatively to the $\mathrm{OB}$ in the area $\mathrm{zx}$

Let's determine the coordinates of the OB relatively to the positions of the UAV at different times. For this we will consider following. The coordinates of the point A $\mathrm{X}_{1}, \mathrm{Z}_{0}$ The coordinates of the point $\mathrm{B}-\mathrm{X}_{2}, \mathrm{Z}_{0}$. Distance from point $A$ to $\mathrm{OB}-\mathrm{R}_{1}$. Distance from point $\mathrm{B}$ to $\mathrm{OB}-$ $\mathrm{R}_{2}$. Based on fig. 2 system of equations that defines the coordinates of OP in time $t$ we'll present as:

$$
\left\{\begin{array}{l}
\mathrm{X}_{\mathrm{OB}}=\mathrm{x}_{2}+\mathrm{R}_{2} \sin \theta_{2} \\
\mathrm{Y}_{\mathrm{OB}}=0 ; \\
\mathrm{Z}_{\mathrm{OB}}=0 .
\end{array}\right.
$$

In accordance with fig. 2 we'll note the corresponding distances as:

$$
\mathrm{AB}=\mathrm{x}_{2}-\mathrm{x}_{1}, \mathrm{BC}=\mathrm{x}_{3}-\mathrm{x}_{2}, \mathrm{AC}=\mathrm{x}_{3}-\mathrm{x}_{1} .
$$

From fig. 2 it shows that the angle

$$
\gamma_{1}=\theta_{1}-\theta_{2}
$$

By lowering the intermediate calculations it can be shown that from the triangle $A B O$ the distance $\mathrm{R}_{2}$ from the point of reference $A$ to the $\mathrm{OB}$ will be expressed by the expression:

$$
\begin{aligned}
\mathrm{R}_{2} & =\left(\mathrm{x}_{1}-\mathrm{x}_{2}\right) \times \\
\times \frac{\sin \alpha}{\sin \left(\theta_{1}-\theta_{2}\right)} & =\left(\mathrm{x}_{2}-\mathrm{x}_{1}\right) \frac{\cos \theta_{1}}{\sin \left(\theta_{1}-\theta_{2}\right)} .
\end{aligned}
$$

Then the OP coordinates can be defined as:

$$
\mathrm{X}_{\mathrm{OB}}=\mathrm{x}_{2}+\left(\mathrm{x}_{2}-\mathrm{x}_{1}\right) \frac{\cos \theta_{1} \sin \theta_{2}}{\sin \left(\theta_{1}-\theta_{2}\right)} .
$$

Let's assume that UAV moved from point $\mathrm{B}$ to point $\mathrm{C}$. Then, according to fig. 2 coordinates of $\mathrm{OB}$ can be defined as follows:

$$
\mathrm{X}_{\mathrm{OB}}=\mathrm{x}_{3}+\left(\mathrm{x}_{3}-\mathrm{x}_{1}\right) \frac{\cos \theta_{1} \sin \theta_{3}}{\sin \left(\theta_{1}-\theta_{3}\right)} .
$$

The right-hand sides of equations (4) and (5) determine the coordinates of the $\mathrm{OB}$, so they can be equated:

$$
\mathrm{x}_{2}+\left(\mathrm{x}_{2}-\mathrm{x}_{1}\right) \frac{\cos \theta_{1} \sin \theta_{2}}{\sin \left(\theta_{1}-\theta_{2}\right)}=\mathrm{x}_{3}+\left(\mathrm{x}_{3}-\mathrm{x}_{1}\right) \frac{\cos \theta_{1} \sin \theta_{3}}{\sin \left(\theta_{1}-\theta_{3}\right)}
$$

Determine the distance between the points B and C:

$$
\mathrm{x}_{3}-\mathrm{x}_{2}=\left(\mathrm{x}_{2}-\mathrm{x}_{1}\right) \frac{\cos \theta_{1} \sin \theta_{2}}{\sin \left(\theta_{1}-\theta_{2}\right)}-\left(\mathrm{x}_{3}-\mathrm{x}_{1}\right) \frac{\cos \theta_{1} \sin \theta_{3}}{\sin \left(\theta_{1}-\theta_{3}\right)}
$$

The equation (7) is the basis for the determination of the PFINS SER. Suppose that under the influence of some factors there was a shift in the position of the UAV in accordance with fig. 3. The magnitude of the displacement is determined by the force of influence on the object of navigation.

Let's assume that there was a shift of UAV from point $\mathrm{B}$ to point $\mathrm{B}^{\prime}$.

Then, in accordance to expression (7), we write:

$$
\Delta \mathrm{X}_{\mathrm{OB}}=\mathrm{Б} \frac{\cos \theta_{1} \sin \theta_{2}}{\sin \left(\theta_{1}-\theta_{2}\right)}-(\mathrm{Б}+\Delta \mathrm{x}) \frac{\cos \theta_{1} \sin \theta_{3}}{\sin \left(\theta_{1}-\theta_{3}\right)}
$$

For small angle deviations $\theta_{3}$ from the angle $\theta_{2}$ expression (8) we write:

$$
\Delta \mathrm{X}_{\mathrm{OB}}=\Delta \mathrm{x} \frac{\cos \theta_{1} \sin \theta_{2}}{\sin \left(\theta_{1}-\theta_{2}\right)} .
$$




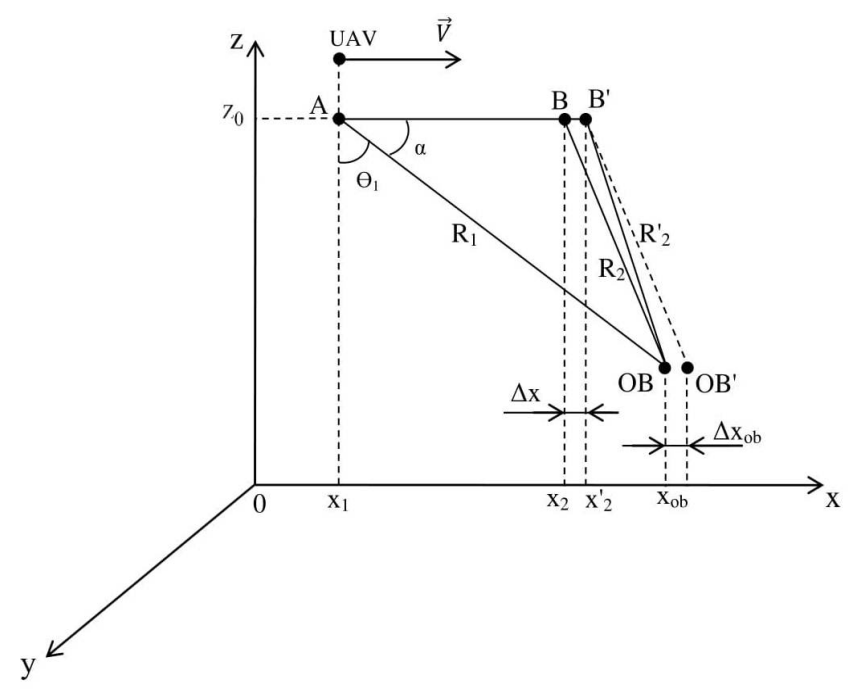

Fig. 3. A displacement of the spatial position of the UAV relatively to the OB in the area $\mathrm{zx}$

Proceeding from (9), the expression for determining the influence of the deviation of the UAV on the determination of the coordinates of the $\mathrm{OB}$ is proposed:

$$
\frac{\Delta \mathrm{X}_{\mathrm{OB}}}{\Delta \mathrm{x}}=\frac{\cos \theta_{1} \sin \theta_{2}}{\sin \left(\theta_{1}-\theta_{2}\right)} .
$$

Let's take into account that, $\Delta \mathrm{x}=\mathrm{Vt}, \mathrm{V}-$ is the rate of displacement of UAV. Then the expression (10) allows us to estimate the error in determining the coordinates of the $\mathrm{OB}$ in dependence, for example, on the rate of wind gusts.

The obtained analytical expressions can be extended to the case when there is a change in the spatial position of the UAV under other parameters. In case of a change in the spatial position of the UAV at the coordinate $\mathrm{Y}$, the system of equations (1) will have the form:

$$
\left\{\begin{array}{l}
\mathrm{X}_{\mathrm{OB}}=\mathrm{x}_{2}+\mathrm{R}_{2} \sin \theta_{2} \\
\mathrm{Y}_{\mathrm{OB}}=\mathrm{y}_{2}+\mathrm{R}_{2} \cos \theta_{2} \\
\mathrm{Z}_{\mathrm{OB}}=0
\end{array}\right.
$$

Taking into account (2) the system (11) will take the form:

$$
\left\{\begin{aligned}
\mathrm{X}_{\mathrm{OB}} & =\mathrm{x}_{2}+\frac{1}{\sin \left(\theta_{1}-\theta_{2}\right)} \times \\
& \times\left[\left(\mathrm{y}_{2}-\mathrm{y}_{1}\right) \cos \theta_{1}-\left(\mathrm{x}_{2}-\mathrm{x}_{1}\right) \sin \theta_{2}\right] \cos \theta_{2} ; \\
\mathrm{Y}_{\mathrm{OB}} & =\mathrm{y}_{2}+\frac{1}{\sin \left(\theta_{1}-\theta_{2}\right)} \times \\
& \times\left[\left(\mathrm{y}_{2}-\mathrm{y}_{1}\right) \cos \theta_{1}-\left(\mathrm{x}_{2}-\mathrm{x}_{1}\right) \sin \theta_{2}\right] \cos \theta_{2} ; \\
\mathrm{Z}_{\mathrm{OB}} & =0 .
\end{aligned}\right.
$$

In accordance with (12), the expressions for determining the influence of the deviation of the UAV on the determination of the coordinates of $\mathrm{OB}$ based on (10) are presented:

$$
\begin{gathered}
\Delta \mathrm{X}_{\mathrm{OB}}(\Delta \mathrm{x})=\frac{\cos \theta_{1} \sin \theta_{2}}{\sin \left(\theta_{1}-\theta_{2}\right)} \\
=\frac{\Delta \mathrm{X}_{\mathrm{OB}}(\Delta \mathrm{y})=}{\sin \left(\theta_{1}-\theta_{2}\right)} \sin \theta_{1} \cos \theta_{2} \Delta \mathrm{y} ; \\
=\frac{\Delta \mathrm{Y}_{\mathrm{OB}}(\Delta \mathrm{x})=}{\sin \left(\theta_{1}-\theta_{2}\right)} \sin \theta_{1} \cos \theta_{2} \Delta \mathrm{x} \\
=\frac{\Delta \mathrm{Y}_{\mathrm{OB}}(\Delta \mathrm{y})=}{\sin \left(\theta_{1}-\theta_{2}\right)} \cos \theta_{1} \sin \theta_{2} \Delta \mathrm{y} ;
\end{gathered}
$$

The influence of the errors of various parameters that determine the orientation of the UAV, on the error of the PFINS link can be found in a linear approximation. This will be done by decomposition of a number of $\mathrm{OB}$ coordinates $\left(\mathrm{X}_{\mathrm{OB}}, \mathrm{Y}_{\mathrm{OB}}\right)$, which can be defined as follows [12]:

$$
\begin{aligned}
& X_{\mathrm{OB}}=F_{1}\left(\mathrm{x}_{1}, \mathrm{x}_{2}, \mathrm{y}_{1}, \mathrm{y}_{2}, \theta_{1}, \theta_{2}\right) ; \\
& \mathrm{Y}_{\mathrm{OB}}=\mathrm{F}_{2}\left(\mathrm{x}_{1}, \mathrm{x}_{2}, \mathrm{y}_{1}, \mathrm{y}_{2}, \theta_{1}, \theta_{2}\right) .
\end{aligned}
$$

As a result, we obtain the expression for the errors of coordinates, which we calculate according to the formulas:

$$
\begin{aligned}
\Delta \mathrm{X}_{\mathrm{OB}}= & \frac{\partial \mathrm{F}_{1}}{\partial \mathrm{x}_{1}} \Delta \mathrm{x}_{1}+\frac{\partial \mathrm{F}_{1}}{\partial \mathrm{y}_{1}} \Delta \mathrm{y}_{1}+\frac{\partial \mathrm{F}_{1}}{\partial \mathrm{x}_{2}} \Delta \mathrm{x}_{2}+ \\
& +\frac{\partial \mathrm{F}_{1}}{\partial \mathrm{y}_{2}} \Delta \mathrm{y}_{2}+\frac{\partial \mathrm{F}_{1}}{\partial \theta_{1}} \Delta \theta_{1}+\frac{\partial \mathrm{F}_{1}}{\partial \theta_{2}} \Delta \theta_{2} \\
\mathrm{Y}_{\mathrm{OB}} & =\frac{\partial \mathrm{F}_{2}}{\partial \mathrm{x}_{1}} \Delta \mathrm{x}_{1}+\frac{\partial \mathrm{F}_{2}}{\partial \mathrm{y}_{1}} \Delta \mathrm{y}_{1}+\frac{\partial \mathrm{F}_{2}}{\partial \mathrm{x}_{2}} \Delta \mathrm{x}_{2}+ \\
& +\frac{\partial \mathrm{F}_{2}}{\partial \mathrm{y}_{2}} \Delta \mathrm{y}_{2}+\frac{\partial \mathrm{F}_{2}}{\partial \theta_{1}} \Delta \theta_{1}+\frac{\partial \mathrm{F}_{2}}{\partial \theta_{2}} \Delta \theta_{2}
\end{aligned}
$$

where $\Delta \mathrm{x}_{1}, \Delta \mathrm{x}_{2}, \Delta \mathrm{y}_{1}, \Delta \mathrm{y}_{2}, \Delta \theta_{1}, \Delta \theta_{2}$ - errors of the initial data;

$$
\frac{\partial \mathrm{F}_{1}}{\partial \mathrm{x}_{1}}, \frac{\partial \mathrm{F}_{1}}{\partial \mathrm{y}_{1}}, \ldots, \frac{\partial \mathrm{F}_{2}}{\partial \theta_{2}}-\text { derivatives of functions } \mathrm{F}_{1}
$$

and $\mathrm{F}_{2}$ on-dependent variable.

By differentiating the expression (18) for each change it is possible to determine the effect of the errors of different parameters that determine the orientation of the UAV. This allows you to find total errors.

Implementation of the developed method is shown in fig. 4 in the form of a structural scheme of the algorithm for determining the coordinates of the SER and the angular orientation parameters of the UAV.

The algorithm is based on the measurement of the distance between the UAV and the corresponding OB, as well as the knowledge of the coordinates of the UAV at the time of implementation of these measurements. 


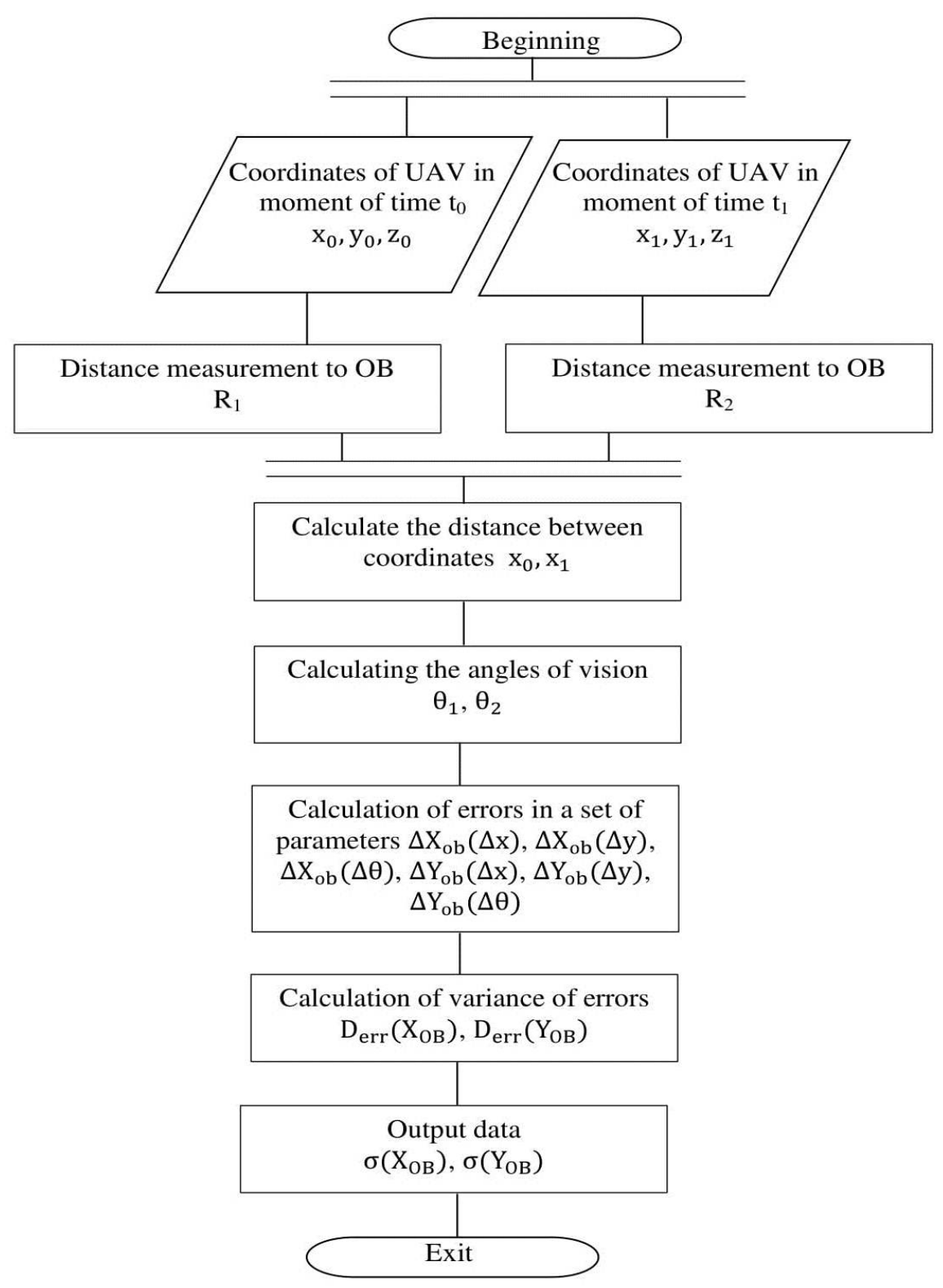

Fig. 4. The block diagram of the algorithm for calculating the SER coordinates of the $\mathrm{OB}$ and the angular parameters of the UAV orientation

In accordance with the structural scheme of the algorithm for the determination of the SER coordinates and angular parameters of the UAV orientation, the focus was on:

- to determine the number of measurements of the distances between the UAV and OB;

- to determine the effect of the displacement of the UAV on the magnitude of the error of orientation.

In the course of statistical simulation, it was considered that the only factor affecting the PFINS is the displacement of the UAV which is due to gusts of wind and air pockets.

According to the results of the statistical modeling, it is established that the determination of the impact of the UAV displacements on the result of the error estimation of the coordinates of the $\mathrm{OB}$ requires that the measurement intervals before the implementation of the correlation-extreme navigation system should be units of meters.
For simulation conditions, shown in Fig. 3, this interval should be about $20 \mathrm{~m}$. In this case, the range of change in the accuracy of the measurement of angular coordinates was within the limits $\sigma \approx(0,05 \ldots 0,2)$ of mrads. In this case, the SER coordinate is provided

$$
\sigma\left(\mathrm{X}_{\mathrm{OB}}\right), \sigma\left(\mathrm{Y}_{\mathrm{OB}}\right)=(5 \ldots 30) \mathrm{m} \text {. }
$$

Numerical calculations of the dependence of the SER on determining the coordinates of the OB from the distance between the measuring points are presented graphically in fig. 5 .

According to the results of statistical simulation of the process of determining the error of the coordinates of the UAV under conditions of influence of wind gusts, it is established that the obtained accuracy of the determination of the coordinates of UAV can be within the limits of several meters of units provided that the accuracy of the measurement of angular coordinates within the limits $\sigma \approx(0,05 \ldots 0,1)$ of mrads is ensured. 


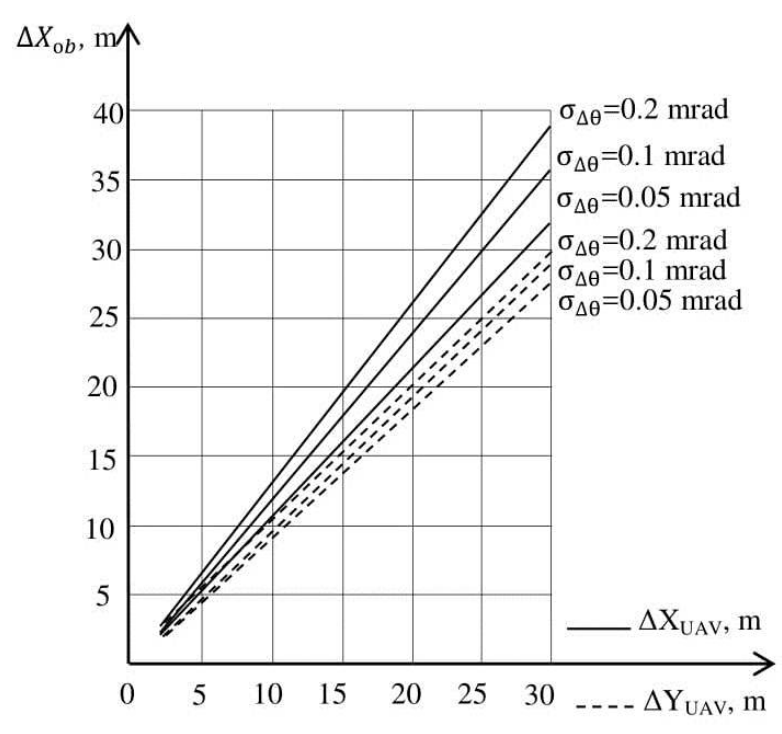

a

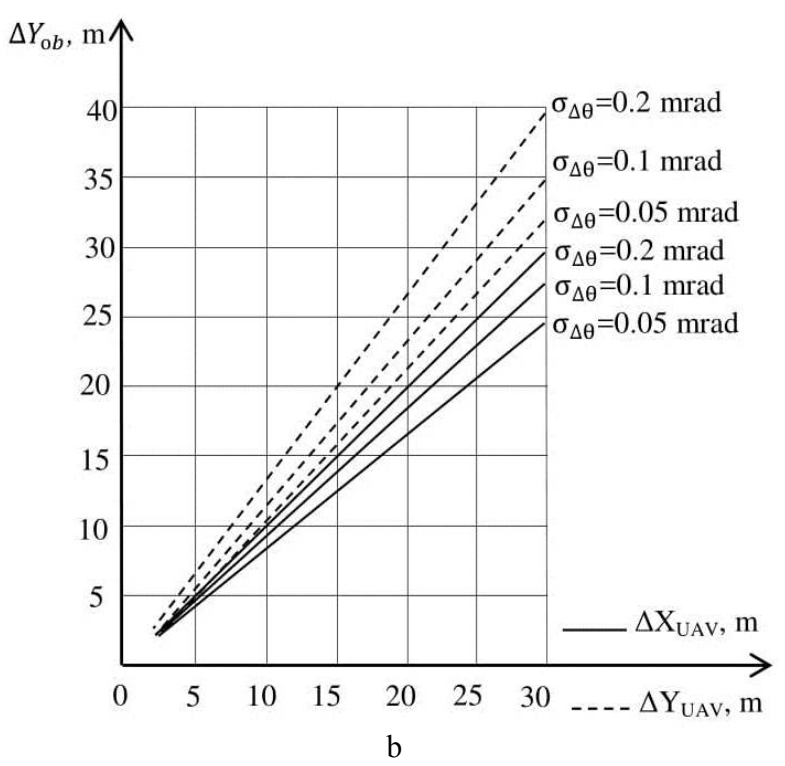

Fig. 5. Results of calculating error coordinates:

$\mathrm{a}-X_{O B} ; \mathrm{b}-Y_{O B}$ depending on the magnitude of the displacement of the UAV

\section{Conclusions}

In the article the method of calculating error coordinates of the $\mathrm{OB}$ and the angular parameters of the UAV orientation is presented, which appears to be under the influence of external factors.

The peculiarity of the method lies in the possibility of forecast and determination of the errors of the coordinates of the OB depending on the direction and force of influence on the UAV.

The developed method can be applied with the restrictions on the mass-dimensional characteristics of the navigation system to calculate the errors of the coordinates of the OB depending on the magnitude of the displacement of the UAV, irrespective to the distance between the points of measurement. The limitations of the application of the method are only the ability of the respective sensors to measure the distances from the UAV to the OB.

The possibility of determining the coordinates of OBs within several meters of units in the conditions of ensuring the accuracy of measuring the angular coordinates by the data sets of the navigation system within the limits of $\sigma \approx(0,05 \ldots 0,1) \mathrm{mrad}$ is shown.

The algorithm for calculating the errors of coordinate OB and angular parameters of the UAV orientation is presented, which is the further development of the sub-algorithm for calculating the angular parameters of the UAV orientation relative to the geographic coordinate system.

\section{REFERENCES}

1. Veremeenko, K.K. and Solovyev, J.A. (2010), “Analys sostoyaniya razrabotok integrirovanuh inercialno-sputnikovuh navigacionuh sistem" [Analysis of the state of development of integrated inertial-satellite navigation systems], News of navigation, No. 4, pp. 32-41.

2. Bezick, S.M., Pue, A.J. and Patzelt, C.M. (2010), “Internal Navigation for Guided Missile Systems”, Johns Hopkins APL technical digest.

3. Borisova, A.Yu. and Smal, A.V. (2017), “Analiz razrabotok sovremenuh besplatvormenuh inercialnuh navigacionuh sistem”, [Analysis of developments of modern, free-of-charge inertial navigation systems], Engineering Herald, No. 5, pp.50-57.

4. Kuznetsov, A.G., Portnov, B.I. and Izmaylov, Ye.A. (2014), "Sovremennyye besplatformennyye inertsial'nyye navigatsionnyye sistemy dvukh klassov tochnosti" [Modern free-of-charge inertial navigation systems of two accuracy classes], Navigation and control of aircraft, No.8, pp. 24-32.

5. Korkishko, Yu.N., Fedorov, V.A., Prilutskiy, V.Ye., Ponomarev, V.G., Morev, I.V., Skripnikov, S.F., Khmelevskaya, M.I., Buravlev, A.S., Kostritskiy, S.M., Zuyev, A.I. and Varnakov, V.K. (2014), "Besplatformennyye inertsial'nyye navigatsionnyye sistemy na osnove volokonnoopticheskikh giroskopov" [Freeform inertial navigation systems based on fiber-optic gyroscopes], Gyroscopy and navigation, No. 1, pp. 14-25.

6. Konovalov, S.F., Ponomarev, Yu.A., Mayorov, D.V., Podchezertsev, V.P. and Sidorov, A.G. (2011), “Gibridnyye mikroelektromekhanicheskiye giroskopy i akselerometry" [Hybrid microelectromechanical gyroscopes and accelerometers], Science and Education of the MSTU N.E. Bauman, No. 10.

7. Bezvesilna, O.M. (2010), "Poshuky shlyakhiv pidvyshchennya tochnosti avtomatychnykh kutovymiryuval'nykh zasobiv" [Finding ways to improve the accuracy of automatic angular measurements], Monograph, ZhDTU, Zhytomyr, $225 \mathrm{p}$.

8. Plaksiy, Yu.A. (2013) "Stepenevi alhorytmy vyznachennya kvaternioniv oriyentatsiyi ta yikh interpolyatsiyni modyfikatsiyi" [Thin algorithms for determination of quaternions of orientation and their interpolation modifications], Bulletin of NTU "KhPI", No. 58 (1031), pp.168-177. 
9. Matveyev, V.V. (2012), "Model pogreshnostey besplatformennoy inertsial'noy navigatsionnoy sistemy" [Model of the errors of the inertial inertial navigation system], Izvestiya TulGU. Engineering Sciences, No. 12 (1), pp. 188-196.

10. Pronkin, A.N., Kuznetsov, I.M. and Veremeyenko, K.K. (2012), "Integrirovannaya navigatsionnaya sistema BPLA: struktura $\mathrm{i}$ issledovaniye kharakteristik" [Integrated navigation system of UAV: structure and study of characteristics], Proceedings of the MAI, No. 41, pp. 12-26.

11. Kortunov, V.I. and Dybskaya, I.Yu., (2006), “Analiz sposobov korrektsii integrirovannykh besplatformennykh inertsial'nykh sistem s nizkotochnymi datchikami v upravlenii letatelnymi aparatami" [Analysis of the ways of correction of integrated freeof-charge inertial systems with low-current sensors in the control of aircrafts], Aviation and space technology, No. 1(27), pp. 38-43.

12. Shivrinskiy, V.N. (2010), "Bortovye vychislitel'nyye kompleksy navigatsii i samolotovozhdeniya" [On-board computing systems for navigation and airplane navigation], a summary of lectures, $148 \mathrm{p}$.

Received (Надійшла) 23.02.2018

Accepted for publication (Прийнята до друку) 25.04.2018

\section{Розрахунковий метод обчислення похибок виміру координат об'єкта прив'язки безплатформенними інерційними навігаційними системами безпілотного літального апарату}

О. М. Сотніков, О. Б. Танцюра, О. Ю. Лавров

Отримано подальший розвиток методу розрахунку похибок координат об'єктів прив'язки та кутових параметрів орієнтації безпілотних літальних апаратів. Похибки визначення координат виникають за рахунок впливу пориві вітру та турбулентностей атмосфери на легкі безпілотні літальні апарати. Особливість методу полягає у спроможності визначати похибки координат об'єктів в залежності від напрямку та сили впливу на безпілотний літальний апарат. Величина зовнішнього впливу визначає величину відхилення від траєкторія руху Розроблений метод може бути застосований при обмежених масогабаритних характеристиках безпілотного літального апарату. Розроблений метод визначає величини похибок вимірів незалежно від відстані між точками вимірювання. Обмеженням застосування методу може бути лише здатність відповідних датчиків вимірювати відстані від безпілотного літального апарата до об'єкта прив'язки. Представлені можливості визначення координат об'єкту прив'язки з точністю в межах одиниць метрів. Це досягається при вимірі кутових координат датчиками навігаційної системи з точністю в межах сотих мілірадіан. Представлений алгоритм розрахунку похибки визначення координат об’єкту прив'язки. Алгоритм є подальшим розвитком субалгоритму обчислення кутових параметрів орієнтації безпілотного літального апарату відносно географічної системи координат. Представлений алгоритм доцільно використовувати перед початком сеансу роботи кореляційно-екстремальної системи навігації. Проведено статистичне моделювання роботи запропонованого методу та алгоритму. Результати моделювання свідчать що величина похибки визначення координат об'єкту прив'язки залежить від точності виміру кутових параметрів безпілотного літального апарату. Представлені результати чисельної оцінки похибок виміру координат об'єктів прив'язки в залежності від точності виміру кутових параметрів безпілотного літального апарату. Визначені вимоги до точності виміру кутових параметрів безпілотного літального апарату при якій забезпечується висока точність виміру прямокутних координат об'єкту прив'язки.

Ключов і слов а: безплатформенна інерційна навігаційна система, об'єкт прив'язки, система прямокутних координат, кути візування

\section{Расчетный метод исчисления ошибок измерения координат объекта привязки бесплатформенными инерциальными навигационными системами беспилотного летательного аппарата}

\section{А.М. Сотников, А.Б. Танцюра, О.Ю. Лавров}

Получил дальнейшее развитие метод расчета ошибок координат объектов привязки и угловых параметров ориентации беспилотных летательных аппаратов. Ошибки определения координат возникают за счет влияния порывов ветра и турбулентностей атмосферы на легкие беспилотные летательные аппараты. Особенность метода заключается в возможности определять ошибки координат объектов в зависимости от направления и силы влияния на беспилотный летательный аппарат. Величина внешнего влияния определяет величину отклонения от траектории движения. Разработанный метод может быть применен при ограничениях на массогабаритные характеристики беспилотного летательного аппарата. Разработанный метод определяет величины ошибок измерений не зависимо от расстояния между точками измерений. Ограничением использования метода может быть лишь способность соответствующих датчиков измерять расстояния от беспилотного летательного аппарата до объекта привязки. Представлены возможности определения координат объекта привязки с точностью в пределах единиц метров. Это достигается при измерении угловых координат датчиками навигационной системы с точностью в пределах сотых мили радиан. Представлен алгоритм расчета ошибки измерения координат объекта привязки. Алгоритм является дальнейшим развитием субалгоритма исчисления угловых параметров ориентации беспилотного летательного аппарата относительного географической системы координат. Представленный алгоритм целесообразно использовать перед началом сеанса работы корреляционно-экстремальной системы навигации. Проведено статистическое моделирование работы предложенного метода и алгоритма. Результаты моделирования свидетельствуют, что величина ошибки определения координат объекта привязки зависит от точности измерения угловых параметров беспилотного летательного аппарата. Представлены результаты численной оценки ошибок измерения координат объектов привязки в зависимости от точности измерения угловых параметров беспилотного летательного аппарата. Определены требования к точности измерения угловых параметров беспилотного летательного аппарата при которой обеспечивается высокая точность измерения прямоугольных координат объекта привязки/

Ключевые слова: бесплатформенная инерциальная навигационная система, объект привязки, система прямоугольных координат, углы визирования. 